\title{
Soluble Transferrin Receptor Measurement
}

National Cancer Institute

\section{Source}

National Cancer Institute. Soluble Transferrin Receptor Measurement. NCI Thesaurus.

Code C100438.

The determination of the amount of soluble transferrin receptor present in a sample. 